\title{
A systematic review of the parasites (Plathelminthes: Trematoda) of the Wels catfish (Silurus glanis L., 1758) N.E. Ibrahimova
}

The Wels catfish or sheatfish (Silurus glanis L., 1758) is one of the important commercial fishes. Its native range extends from Eastern Europe to Western Asia. Recently, the species range has expanded both to the west and south due to the introduction. In the water bodies of Azerbaijan, the Wels catfish exists at the southernmost border of its range. It was recorded from the Kura River and its basin. There is no survey of parasitological studies on the trematodes of the Wels catfish. The previous papers have not covered all systematic groups or all the areas where the fish is distributed. Based on the literature data, we prepared a systematic review of the Wels catfish trematodes within the catfish present-day range (native area plus the areas of introduction), including Azerbaijan. The list is given according to the system of parasitic organisms implemented in the Catalog of parasites of freshwater fishes of North Asia. We also took into account new studies in the trematode taxonomy. Each species is provided with the following data: synonyms, habitat in the fish body, collecting localities, geographic distribution within the catfish range, infection rates, and references. As a result, 33 trematode species were found in the Wels catfish. They belong to three orders (Aspidogastridea - 1 species, Strigeida - 16 species, and Plagiorchiida - 16 species), 15 families and 24 genera. Of these, 14 species are distributed in the waterbodies of Azerbaijan. The family Diplostomidae (9 species) dominates among the Wels catfish' trematode parasites. The most Wels catfish trematodes within its whole range are Bucephalus polymorphus, Orientocreadium siluri and Diplostomum spathaceum. We established that Aspidogaster limacoides, Plagioporus skrjabini, Phyllodistomum petruschewskii were recorded from Ukraine only, Allocreadium siluri and Bolboforus confusus, from Uzbekistan, and Asymphylodora kubanica, Bychowskycreadium bychowsky, Bychowskycreadium schiliani, Diplostomum mergi, Diplostomum chromatophorum, and Diplostomum paraspathaceum from Azerbaijan.

Key words: trematodes, systematic list, Wels catfish parasites, infection rates, geographical distribution.

\section{About the author:}

N.E. Ibrahimova - Institute of Zoology, Azerbaijan National Academy of Sciences, A. Abbaszadeh Str., passage 128, block 504, Baku, Azerbaijan, AZ1004, ibragimova.n.e@mail.ru, https://orcid.org/0000-0002-4531-3823

The Wels catfish or sheatfish (Silurus glanis L., 1758) is one of the most important commercial predatory fishes. It ranks among the 20 largest freshwater fish species in the world (Stone, 2007). The Wels catfish native geographic range extends from Eastern Europe to Western Asia (Kinzelbach, 1992). Due to the introduction, the present-day area of the catfish distribution has expanded to the west and south and covered at least seven new countries (Elvira, 2001). In the water bodies of Azerbaijan, the Wels catfish exists at the southernmost border of its range; it occurs in the Kura River and its basin (lakes and the Shamkir, Mingachevir, Varvara, and Yenikend Water Reservoirs) (Mikailov, Ibrahimova, 2001). There are no parasitological surveys concerning the studies on the flukes (trematodes) of the Wels catfish. The previous papers have not covered all systematic groups or all the areas where the fish is distributed. Therefore, we considered it appropriate to summarize literature data and make a systematic survey of the Wels catfish trematodes within its range (native area plus the areas of introduction), including Azerbaijan.

We followed a system of parasitic organisms implemented in the Catalogue of parasites of the freshwater fishes of North Asia (Pugachev, 2003). We also took into consideration the modern research in trematode taxonomy (Gibson, 1996; Gibson et al., 2002; Jones et al., 2005). In addition, we used the data presented in the book "Identification guide to the parasites of freshwater fishes of the USSR" (Scarlato, 1987).

Based on the literature data, 33 species of trematode parasites were reported to invade the Wels catfish. All the species are listed below in systematic order. Each species is provided with the following data: synonyms, habitat in the fish body, collecting localities and geographic distribution within the catfish range, prevalence $(\mathrm{PI})$ and intensity $(\mathrm{II})$ of infection, literature sources. 
Phylum: Plathelminthes Gegenbaur, 1859

Class: Trematoda Rudolphi, 1808

Class taxonomy after D. Gibson, 1996

Order: Aspidogastridea Faust, 1932

Family: Aspidogastridae Poche, 1907

Genus: Aspidogaster Baer, 1827

Species: Aspidogaster limacoides Deising, 1835

Habitat: intestine

Geographical distribution: rivers of the Black Sea, the Sea of Azov, and the Caspian Sea basins (Markevich, 1951).

Order: Strigeida La Rue, 1926

Suprafamily: Diplostomoidea Poirier, 1886

Family: Diplostomidae Poirier, 1886

Genus: Posthodiplostomum Dubois, 1936

Syn.: Holostomum Nitzsch, 1816 part.; Diplostomum Nordmann, 1832 part.; Diplostomulum Brandes, 1892 part.; Neascus Hughes, 1927; Posthodiplostomum Dubois, 1938). Synonymy after Sudarikov, 1971.

Species: Posthodiplostomum cuticola Nordmann, 1832

Syn.: Holostomum cuticola Nordmann, 1832; Diplostomum cuticola (Nordm., 1832) Diesing, 1850; Diplostoma cuticola Dies.-Cobbold, 1860; Tetracotyle cuticola (Nordm., 1832) Kowalewski, 1902; Diplostomulum cuticola (Nordm., 1832) Faust, 1917; Neascus cuticola (Nordm., 1832) Hughes, 1927; Posthodiplostomum cuticola (Nordm.) Dubois, 1937. Synonymy after Sudarikov, 1971.

Habitat: skin and subcutaneous tissue, muscles, brain.

Geographical distribution: Kazakhstan - Aral Sea (PL 20 \%) (Agapova, 1966); Uzbekistan - Amu Darya mouth, Mashankul Lake and other Kungrad lakes (metacercaria PL $3.3 \%$ ), Aral Sea (Muynak, PL $5.5 \%$, II 1 ind.) (Osmanov, 1971); Azerbaijan - Shamkir Water Reservoir (PL $50 \%$, II 2-5 ind.), Kura mouth (PL $60 \%$, II 4-8 ind.) (Ibrahimova, Mursalov, 2000; Mikailov, Ibrahimova, 2001; Mikailov et al., 2001; Ibrahimova, 2003).

Subfamily: Diplostominae Poirier, 1886

Genus: Diplostomum Nordmann, 1832 1971.

Syn.: Diplostomulum Brandes, 1892; Tetracotyle de Filippi, 1854 part. Synonymy after Sudarikov,

Note. Species composition of the Genus Diplostomum is so far a subject of a lively discussion due to obvious contradictions of the opinions of many authors (see Niewiadomska, 1984, 1986; Shigin, 1986, 1987). I, like O. Pugachev (2003), hold with A. Shigin taxonomy $(1976,1986,1993)$ solely in the sake of convenience and unified approach to the analyzed material.

Species: Diplostomum chromatophorum Braun, 1893

Syn.: Diplostomum volvens Nordmann, 1832 part.; Tetracotyle volvens (Nordmann, 1832) Matare, 1909 part.; Diplostomum volvens (Nordmann, 1832) Faust, 1918 part.; Diplostomulum spathaceum (Rud., 1819) Hughes, 1929; Diplostomi spathacei (Rud., 1819) = Diplostomulum spathaceum (Rud., 1819) Hughes, 1929 sensu Sudarikov, 1960 part.; Diplostomum spathaceum (Rud., 1819) sensu Shigin, 1965, 1968, Pugachev, 1983, 1984; Diplostomum spathaceum (Rud., 1819) Braun, 1893 sensu Sudarikov, 1971. Synonymy after Shigin, 1986 with additions.

Habitat: lens of the eye.

Geographical distribution: Azerbaijan - Lesser Kyzylagach Bay (PL $20 \%$ ) (Ibrahimov, 1977), Greater Kyzylagach Bay (PL $20 \%$, II 3-8 ind.) (Seyidli, 1992), Yenikend Water Reservoir (PL 11.1\%, II 2-3 ind.) (Ibrahimova, Mikailov, 2006; Ibrahimova, 2008a, 2008b, 2009, 2010).

Species: Diplostomum mergi Dubois, 1932

Syn.: Diplostomum niedashui Pan et Wang, 1963. Synonymy after Shigin, 1986.

Habitat: lens of the eye.

Geographical distribution: Azerbaijan - Yenikend Water Reservoir (PL 11.1\%, II 3-5 ind.) (Ibrahimova, Mikailov, 2006; Ibrahimova, 2008a, 2008b, 2009, 2010).

Species: Diplostomum spathaceum Rudolphi, 1819 
Syn.: Diplostomum macrostomum Shigin, 1965; Diplostomum erythrophthalmi (Shigin, 1965) Shigin, 1969; Diplostomum flexicaudum (Cort et Brooks, 1928) Van Haitsma, 1931 part. Synonymy after Shigin, 1986.

Habitat: lens of the eye.

Geographical distribution: Kazakhstan - Aral Sea (PL $20 \%$ ), Syr Darya River (PL $24 \%$ ), Bilikol Lake (PL $8.8 \%$ ), Sarysu River (PL 28 \%) (Agapova, 1966); Uzbekistan - Syr Darya River (PL 30,7 \%; II 1 ind.), Amy Darya River and Sudochye Lake (PL $20 \%)$, Khozhakul Lake (PL $23.5 \%$ ), Aral Sea (Muynak - PL 13.3-55.5\%; II 1-13 ind.; Sorkul - PL 66.6\%; II 2-12 ind.; Zamansay - PL 14.8 \%), Tomaruzyak (II 2-5 ind.), Korp (PL $20 \%$; II 1-8 ind.), Ordabay (PL $25 \%$; II 5 ind.), Karaten (PL $14.3 \%$; II 2 ind.), Kabanbay (PL 33 \%; II 2-23 ind.), Akpitki (PL $21 \%$; II 1-9 ind.) (Osmanov, 1971). A high infection rates of the catfish by $D$. spathaceum metacercaria was registered in the Sarybas Water Reservoir in the Amy Darya estuary (PL 81.25 \%) (Kurbanova et al., 2002). Turkey - Sapanca Lake (Soylu, 1990); Iran Gilan Province (Javad et al., 2014; Khara, Sattari, 2016); Iraq - Zab River (Furhan, Shamall, 2017); Czech Republic and Slovak Republic (Moravec, 2001); Latvia - Alūksnes, Burtnieku, Cirma, Durbes, Juglas, Kāla, Lielauces, Liepājas, Rāznas, Rušons, Sildu, Sīvers, Slokas, Usmas Lakes; Kegums Water Reservoir; Daugava, Līčupe, Ogre, Rītupe, Salaca Rivers; Gulf of Riga (Kirjušina, Vismanis, 2007); Azerbaijan - Kyzylagach Bay (PL 13.3 \%, II 1-3 ind.) (Seyidli, 1992), Kura mouth (PL $26.6 \%$, II 2-4 ind.) (Ibrahimova, Mursalov, 2000; Mikailov, Ibrahimova, 2001; Mikailov et al., 2001; Ibrahimova, 2008a).

Species: Diplostomum paraspathaceum Shigin, 1965

Syn.: Diplostomum huronense (La Rue, 1927) Hughes, 1929; Proalaria huronense La Rue, 1927; Diplostomum huronense (La Rue, 1927) Hughes et Hall, 1929 part.; Diplostomum spathaceum (Rudolphi, 1819) Dubois et Rausch, 1950; Diplostomum spathaceum (Rudolphi, 1819) Braun, 1893; Diplostomum paraspathaceum. Synonymy after Shigin, 1965.

Habitat: lens of the eye.

Geographical distribution: Azerbaijan - Southern Caspian (PL 13.3 \%) (Ibrahimov, 1977); Yenikend Water Reservoir (II 3 ind.) (Ibrahimova, Mikailov, 2006; Ibrahimova, 2008a, 2010).

Species: Diplostomum paracaudum lles, 1959

Habitat: lens of the eye.

Geographical distribution: Azerbaijan - Varvara Water Reservoir (PL $28.6 \%$, II 2-5 ind.) (Kazieva, 1984); Yenikend Water Reservoir (II 2 ind.) (Ibrahimova, Mikailov, 2006; Ibrahimova, 2008a, 2008b, 2009, 2010).

Genus: Hysteromorpha Lutz, 1931

Syn.: Holostomum Nitzsch, 1816 part.; Diplostomum Nordmann, 1832 part.; Tetracotyle de Filippi, 1854 part.; Diplostomulum Brandes, 1892 part.; Neascus Hughes, 1927 part. Synonymy after Sudarikov, 1971.

Species: Hysteromorpha triloba Rudolphi, 1819

Syn.: Holostomum musculicola Waldenburg, 1860; Diplostomum musculicola (Waldenburg, 1860) Braun, 1892; Tetracotyle musculicola (Waldenburg, 1860) Braun, 1894; T. musculorum percae (Waldenburg, 1860) Matare, 1909; Neascus musculicola (Waldenburg, 1860) Hughes, 1928; Diplostomulum corti Hughes, 1929; Diplostomum trilobum (Rd., 1819) Ciurea, 1930; Diplostomulum trilobum (Rud., 1819) Ciurea, 1938. Synonymy after Sudarikov, 1971.

Habitat: musculature (predominantly back muscles), less common under the skin.

Geographical distribution: Uzbekistan - Amy Darya mouth, Mashankul Lake and other Kungrad lakes (PL 31.56 \%; II 5-95 ind.), Akpitki (PL 6.2\%), Tomaruzyak (PL 13.3\%; II 1-142 ind.), Aral Sea (Muynak - PL $27.7 \%$; II 4-50 ind.) (Osmanov, 1971).

Genus: Tylodelphys Diesing, 1850

Syn.: Diplostomum Nordmann, 1832 part.; Tetracotyle de Filippi, 1854 part.; Diplostomulum Brandes, 1892 part.). Synonymy after Sudarikov, 1971.

Species: Tylodelphys clavata Nordmann, 1832

Syn.: Diplostomum clavatum Nordmann, 1832; Diplostoma clavatum Nordm., 1832 sensu Cobbold, 1860; Tetracotyle clavata sensu Matare, 1910; Diplostomulum clavatum (Nordmann, 1832) Hughes, 1929; Tylodelphys conifera (Mehlis, 1846) Dubois, 1937 sensu Kozicka et Niewiadomska, 1960. Synonymy after Sudarikov, 1971.

Habitat: vitreous humor of eye. 
Geographical distribution: Uzbekistan - Aral Sea (Muynak - PL 22.2\%), Khozhakul Lake (Osmanov, 1971); Turkey - Sapanca and Sığırcı Lakes (Soylu, 1990; Hafize, 2013); Czech Republic and Slovak Republic (Moravec, 2001).

Species: Bolboforus confusus Krause, 1914

Genus: Bolboforus Dubois, 1935

Habitat: muscles, under the skin (is recorded to be found in the vitreous humor of eye and in gills).

Geographical distribution: Uzbekistan - Amy Darya basin (Zhamansay), Aral Sea (Sorkul - PL $8.2 \%$; II 2 ind.) (Osmanov, 1971).

Family: Strigeidae Railliet, 1819

Family taxonomy after Sudarikov, 1984.

Subfamily: Cotylurinae Dubois, 1936

Genus: Ichthyocotylurus Odening, 1969

Species: Ichthyocotylurus pileatus Rudolphi, 1802

Syn.: Festucaria pileata Rudolphi, 1802; Monostomum pileatum (Rud.) Zeder, 1803; Amphistoma pileatum (Rud.) Rudolphi, 1819; Holostomum pileatum (Rud.) Blainville, 1828; Cotylurus pileatus (Rud.) Dubois, 1937; Cotylurus medius Dubois et Bausch, 1950; Tetracotyle diminuta Hughes, 1928). Synonymy after Sudarikov, 1984.

Habitat: swim bladder walls, heart region, kidneys, less common in the tissues of other organs.

Geographical distribution: Czech Republic (Gordon et al., 2009).

Species: Ichthyocotylurus variegatus Creplin, 1825

Syn.: Amphistoma variegatum Creplin, 1825; Holostomum variegatum (Creplin, 1825) Dujardin, 1845; Holostomum variegatum Duj. Sensu Dujardin, 1850; Holostoma variegatum Duj. sensu Cobbold, 1860; Strigea variegata (Creplin, 1825) Lühe, 1909 part.; Cotylurus variegatus (Creplin, 1825) Szidat, 1928; Cotylurus (Ichthyocotylurus) variegatus (Creplin, 1825) sensu Odening, 1969 part.; Cotylurus platycephalus (Creplin, 1825) part.; Cotylurus pileatus (Rudolphi, 1802) part.; Cotylurus cumulitestis Dubois, 1962; Tetracotyle variegata (Creplin, 1825); Tetracotyle ex Perca fluviatilis Moulinie, 1856; Tetracotyle typica sensu Dujardin, 1858, T. typica de Filippi, 1854; Tetracotyle percae fluviatilis (Moulinie) Diesing, 1858; Tetracotyle percae fluviatilis (Moulinie) Linstow, 1877; Tetracotyle percae Zschokke, 1884; Tetracotyle percae fluviatilis Linstow, 1877. Synonymy after Sudarikov, 1984.

Habitat: swim bladder walls, gonads, kidneys, less common in the tissues of other organs.

Geographical distribution: not identified (Scarlato, 1987).

\section{Suprafamily: Gymnophalloidea Odhner, 1905 \\ Family: Bucephalidae Poche, 1907 \\ Genus: Bucephalus Baer, 1827}

Species: Bucephalus polymorphus Baer, 1827 (Fig. 1).

Syn.: Gasterostomum fimbriatum Siebold, 1848; Gasterostomum laciniatum Molin, 1859; Bucephalus markewitschi Koval, 1949.

Habitat: intestine.

Geographical distribution: Kazakhstan - Syr Darya (PL $2 \%$ ) (Agapova, 1966); Russia - Volga River near Samara (PL 13.2 \%; II 9.5 ind.) (Kirillov et al., 2018); Turkey - Sapanca Lake (Soylu, 1990); Czech Republic and Slovak Republic (Moravec, 2001); Latvia - Burtnieku, Durbes, Juglas, Rāznas, Sildu, Sìvers, Slokas, Usmas Lakes; Kegums Water Reservoir; Daugava, Rītupe, Salaca Rivers (Kirjušina, Vismanis, 2007); Azerbaijan - coast of the Southern Caspian (PL 14.3\%) (Mikailov, 1975), Yenikend Water Reservoir (PL 11.1\%, II 2 ind.) (author's data).

Genus: Rhipidocotyle Diesing, 1858

Species: Rhipidocotyle campanula Dujardin, 1845

Syn.: Distoma campanula Dujardin, 1845; Gasterostomum illense Ziegler, 1883; Bucephalus polymorphus in Lühe, 1909 part. sensu Koval, 1959; Rhipidocotyle illense (Ziegler, 1883) Vejnar, 1956 sensu Skrjabin et Guschanskaja, 1962. Synonymy after Bykhovskaya, Kulakova, 1987 with additions.

Habitat: adult individuals in the intestine, incysted metacercaria in the gills, fins, muscles, eyes, brain, subcutaneous tissue.

Geographical distribution: Uzbekistan - Aral Sea (PL $10 \%$ ), Amy Darya (PL 11.7 \%; II 25-39 ind.) and Syr Darya basins (Osmanov, 1971); Russia - Volga River near Klimovka Vill. (PL $12.5 \%$; II 6- 
19 ind.) (Kirillov et al., 2018); Azerbaijan - coast the Southern Caspian (Mikailov, 1975), in the South Caspian Sea (PL $33.3 \%$ ) (Ibrahimov, 1977), and the Yenikend Water Reservoir (PL $27.8 \%$, II 2-5 ind.) (Ibrahimova, Mikailov, 2006; Ibrahimova, 2008a, 2008b, 2009, 2010).

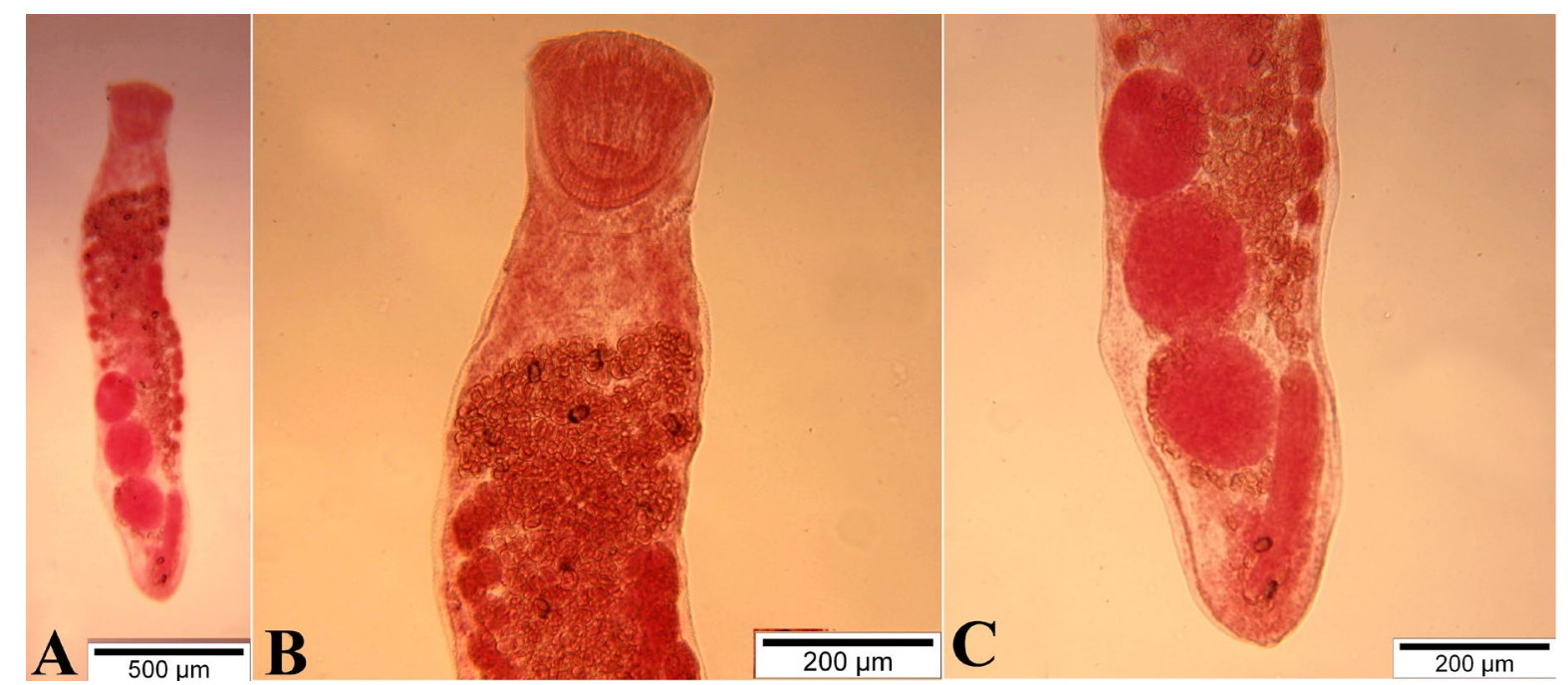

Fig. 1. Trematode Bucephalus polymorphus. A - general view, B - enlarged anterior end with oral sucker, C - enlarged posterior end. Photo: N. Ibrahimova

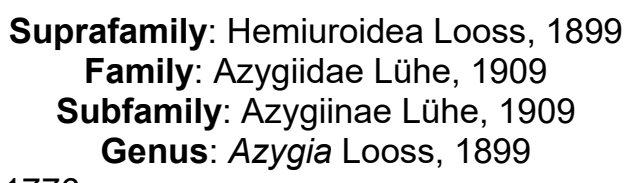

Species: Azygia lucii Müller, 1776

Syn.: Fasciola lucii Müller, 1776; Planaria lucii (Müller, 1776) Goeze, 1782; Distoma lucii (Müller, 1776) Zeder, 1800; Fasciola tereticollis Rud., 1802; Distoma tereticolle (Rud., 1802) Rud., 1809; Distoma rosaceum Nordmann, 1832; Azygia tereticollis (Rud., 1802) Looss, 1899; Azygia lucii johanseni Pavlov, 1931). Synonymy after Skryabin, Gushanskaya, 1956.

Habitat: esophagus and stomach.

Geographical distribution: Serbia (Djikanovic et al., 2012); Czech Republic and Slovak Republic (Moravec, 2001); Georgia - Japana Lake, Poti area (Murvanidze et al., 2018).

Family: Bunocotylidae Dollfus, 1950

Genus: Bunocotyle Odhner, 1928

Species: Bunocotyle cingulata Odhner, 1928

Habitat: intestine.

Geographical distribution: Iran - Gilan, Anzali and Mazandaran Provinces (Sefidkare-Langeroudi, 1965; Mokhayer, 1976; Pazooki, Masoumian, 2012).

Family: Orientocreadiidae Skryabin et Kowal, 1960

Genus: Orientocreadium Tubangui, 1931

Species: Orientocreadium siluri Bychowsky et Dubinina, 1954

Habitat: intestine.

Geographical distribution: Uzbekistan - Aral Sea (PL $15.5 \%$; II 1-8 ind.), Amy Darya basin (Surkhan Darya, Vakhsk Rivers - PL $31.8 \%$ ), Zerafshan (PL $23.5 \%$; II 1-3 ind.), Amy Darya (PL 30.9$31 \%$; II 1-18 ind.), Syr Darya (PL 61.5 \%; II 1-40 ind.) Rivers (Osmanov, 1971); Kazakhstan - Ural (PL $3.5 \%$ ), Syr Darya (PL 28 \%) Rivers (Agapova, 1966); Russia - Saratov Water Reservoir (Mordovinskaya Pojma - PL $5.6 \%$ ) (Kirillov et al., 2018); Georgia - Tekhura River, Bebesiri Lake (Murvanidze et al., 2018); Iraq - Zab River (Furhan, Shamall, 2017); Iran - Gilan Province (PL 60.47 \%; II 1-14 ind.) (Javad et al., 2014); Turkey - Sapanca Lake (Soylu, 1990). The species was found in Europe, in the basins of 
the Black Sea, the Sea of Azov, and the Caspian Sea (Rubanova, Rubanov, 2015; Kirillov et al., 2018); Azerbaijan - coast of the Southern Caspian (PL $33 \%$ ), water bodies in the Kura basin (PL $6 \%$, II 115 ind.) (Mikailov, 1975), Hajikabul Lake (PL 5.4 \%, II 5-9 ind.) (Abdullayeva, 1971), in the South Caspian Sea (PL 13.3\%) (Ibrahimov, 1977).

Order: Plagiorchiida La Rue, 1957

Suprafamily: Allocreadioidea Looss, 1902

Note: K.I. Skryabin and V.P. Koval (1966) identified this suptafamily as Allocreadioidea Nicoll, 1934 (Skryabin, Koval, 1966).

Family: Allocreadiidae Looss, 1902

Note: K.I. Skryabin and V.P. Koval (1966) identified this family as Allocreadiidae Stossich, 1903 (Skryabin, Koval, 1966). D. Gibson (Gibson, 1996) does not admit the family Bunoderidae Nicoll, 1914 and concerns the genera Bunodera, Crepidostomum, and Acrolichanus as part of the family Allocreadiidae.

Genus: Allocreadium Looss, 1900

Syn.: Creadium Looss, 1899; Macrolecithus Hasegawa et Ozaki, 1926 part. Synonymy after Skryabin, Koval, 1966 with additions.

Note. The Genus taxonomy is so far a subject of discussions. For instance, the validity of some species (namely A. baueri, A. papilligerum, and A. carparum) needs confirmation.

Species: Allocreadium siluri Osmanov, 1967

Habitat: intestine.

Geographical distribution: Uzbekistan - Syr Darya mouth (PL 14.2 \%; II 10 ind.) (Osmanov, 1971).

Genus: Bychowskycreadium Mikailov, 1967

Note. The genus Bychowskycreadium with two species was discovered and described from Lake Shilyan in Azerbaijan (Mikailov, 1975). In the Caspian Sea basin, this genus proved to be as rare as a close genus Orientocreadium. Further, Bychowskycreadium has not been registered in the Republic, since Shilyan Lake, the only known locality, was drained. Therefore, the genus was lost. Later on, Bychowskycreadium was synonymized with the genus Allocreadium (Scarlato, 1987), that we consider erroneous. In our opinion, Bychowskycreadium differs from both Allocreadium (a specialist cyprinids' parasite) and Orientocreadium by main morphological features. We tend to insist that Bychowskycreadium is a valid genus. For this reason, we list here both species, described by T.K. Mikailov, in the genus Bychowskycreadium.

Species: Bychowskycreadium bychowsky Mikailov, 1967 (Fig. 2A)

Habitat: intestine.

Geographical distribution: Azerbaijan - Shilyan Lake (PL 16 \%; II 1-15 ind.) (Mikailov, 1975).

Species: Bychowskycreadium schiliani Mikailov, 1967 (Fig. 2B)

Habitat: intestine.

Geographical distribution: Azerbaijan - Shilyan Lake (PL 3.2 \%; II 47 ind.) (Mikailov, 1975).

Genus: Bunodera Railliet, 1896

Syn.: Bunoderina Miller, 1936; Allobunodera Yamaguti, 1971. Synonymy after Gibson, 1996.

Species: Bunodera luciopercae Müller, 1776

Syn.: Fasciola luciopercae O.F. Müller, 1776; F. percae cernuae O.F. Müller, 1776; Planaria lagena Braun, 1788; Fasciola percae Gmelin, 1790; F. percina Schrank, 1790; Bunodera nodulosa (Frölich, 1791) Railliet, 1896; Distoma nodulosus Zeder, 1800; Crossodera nodulosa Cobbold, 1860; Distomum nodulosum (Zeder) Looss, 1894; Bunodera nodulosa (Looss, 1899). Synonymy after Skryabin, Koval, 1966.

Habitat: intestine.

Geographical distribution: water bodies of the Northern America and Western Europe; also in the basins of the White, Baltic, Black Seas, the Sea of Azov, the Caspian Sea, and the rivers of Siberia (Markevich, 1951). Russia - Volga River near Samara (PL 20.0\%; II 2-7 ind.) (Kirillov et al., 2018); Czech Republic and Slovak Republic (Moravec, 2001); Azerbaijan - water bodies of the Kura basin (PL $3.2 \%$, II 2 ind.) (Mikailov, 1975).

Family: Opecoelidae Ozaki, 1925

Subfamily: Plagoporinae Manter, 1947 
Genus: Sphaerostomum Stiles et Hassal, 1898

Species: Sphaerostomum bramae Müller, 1776

Syn.: Fasciola bramae Müller, 1776; Sphaerostomum majus Janiszewska, 1949. Synonymy after Bykhovskaya, Kulakova, 1987.

Habitat: intestine.

Geographical distribution: Czech Republic and Slovak Republic (Moravec, 2001).

A

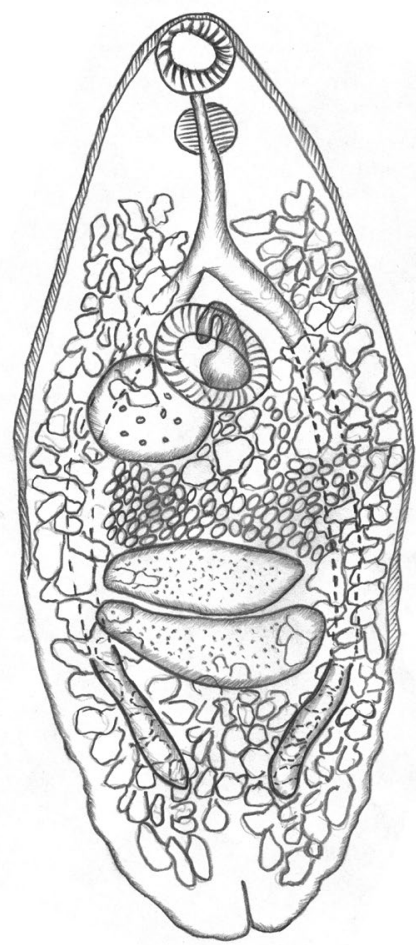

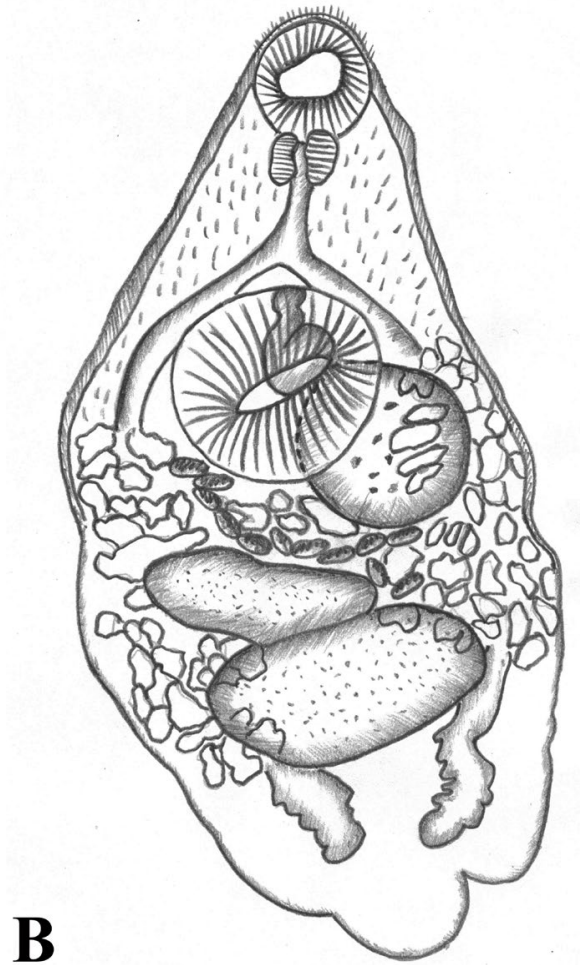

B

Fig. 2. Species of the Genus Bychowskycreadium. A - B. bychowsky. B - B. schiliani (after Mikailov, 1975)

Family: Opecoelidae Ozaki, 1925

Genus: Nicolla Wisniewski, 1944

Species: Nicolla skrjabini Iwanitzky, 1928

Син: Crowcrocoecum skrjabini Iwanitzky, 1928

Habitat: intestine.

Geographical distribution: basins of the Baltic, Black and Caspian Seas (Scarlato, 1987). Russia Saratov Water Reservoir (Mordovinskaya Pojma - PL 26.7 \%) (Mineeva, 2016; Kirillov et al., 2018); Czech Republic and Slovak Republic (Moravec, 2001); Iran - Zarrin River (PL 39 \%) (Yakhchali et al., 2012); Latvia - Daugava River, Kegums Water Reservoir (Kirjušina, Vismanis, 2007).

Genus: Plagioporus Stafford, 1904

Species: Plagioporus skrjabini Kowal, 1951

Habitat: intestine.

Geographical distribution: basins of the Danube and Dnieper Rivers (Scarlato, 1987).

Suprafamily: Plagiorchioidea Lühe, 1901

Family: Gorgoderidae Looss, 1899

Subfamily: Phyllodistominae Nybelin, 1926

Genus: Phyllodistomum Braun, 1899

Syn.: Spathidium Looss, 1899; Catoptroides Odhner, 1902; Microlecithus Ozaki, 1926; Vitellarinus Zmeev, 1936; Gorgotrema Dayal, 1938 part. Synonymy after Pigulevsky, 1953. 
Note. The genus taxonomy is extremely confusing and requires careful research. Many features used as species diagnostic characteristics are highly variable due to different habitats in the host body and functioning of reproductive system (Kudinva, 1979, 1990, 1994; Pugachev, 2003).

Species: Phyllodistomum folium Olfers, 1816

Syn.: Distomum folium Olfers, 1816 nec $D$. folium Rud., 1819; Phyllodistomum folium (Olfers, 1816) Braun, 1899; Ph. phoxini Razmaschkin, 1974. Synonymy after Pigulevsky, 1953 and Bykhovskaya, Kulakova, 1987.

Habitat: ureters and urinary bladder. 2018).

Geographical distribution: Russia - Saratov Water Reservoir (PL 6.7 \%; II 2 ind.) (Kirillov et al.,

Species: Phyllodistomum petruschewskii Pigulewsky, 1953

Syn.: Phyllodistomum pigulewskyi Razmaschkin, 1974

Habitat: urinary bladder.

Geographical distribution: Ukraine - Southern Buh River (Scarlato, 1987).

Species: Phyllodistomum simile Nybelin, 1926

Syn.: Distomum folium Zschokke, 1884 part. nec D. folium Olfers, 1816; Phyllodistomum folium Lühe, 1909 part. Synonymy after Pigulevsky, 1953.

Habitat: ureters and urinary bladder.

Geographical distribution: basins of the White, Baltic, Black and Caspian Seas (Scarlato, 1987).

Suprafamily: Zoogonoidea Odhner, 1902

Family: Monorchiidae Odhner, 1911

Genus: Asymphylodora Looss, 1899

Species: Asymphylodora tincae Modeer, 1790

Syn.: Distoma tincae Modeer, 1790; Distomum perlatum Nordmann, 1832; Asymphylodora perlata (Nordmann, 1832) Looss, 1899. Synonymy after Sobolev, 1955.

Habitat: intestine.

Geographical distribution: widely spread throughout Tinca tinca L., 1758 range (Scarlato, 1987).

Species: Asymphylodora kubanica Issaitschikoff, 1923

Habitat: intestine.

Geographical distribution: Azerbaijan - coast of the Southern Caspian (PL 28.6 \%) (Mikailov, 1975).

Suprafamily: Schistosomatoidea Stiles et Hassall, 1898

Family: Clinostomidae Luhe, 1901

Genus: Clinostomum Leidy, 1856

Species: Clinostomum complanatum Rudolphi, 1819

Habitat: muscles under the skin and body cavity.

Geographical distribution: Uzbekistan - Aral Sea (PL 2.2-3.8 \%; II 1-2 ind.), Amy Darya basin, Vakhsh River (PL $2.3 \%$ ) (Osmanov, 1971); Azerbaijan - coast of the Southern Caspian (PL 42 \%, II 1-3 ind.) (Mikailov, 1975), Southern Caspian area (PL 6.7 \%) (Ibrahimov, 1977).

Suprafamily: Opisthorchioidea Looss, 1899

Family: Heterophyidae Odhner, 1914

Genus: Metagonimus Katsurada, 1913

Species: Metagonimus yokogawai Katsurada, 1912

Habitat: scale and fins.

Geographical distribution: basins of the Black (Dnieper, Dniester, Danube Rivers) and Caspian Seas (Markevich, 1951); Czech Republic and Slovak Republic (Moravec, 2001).

Species: Pygidiopsis geneta Looss, 1907

Genus: Pygidiopsis Looss, 1907

Habitat: gills and muscles (superficial layers of the anterior half of the body). 1987).

Geographical distribution: basins of the Black Sea, Sea of Azov, and the Caspian Sea (Scarlato, 
Suprafamily: Hemiuroidea Looss, 1899

Family: Hemiuroidae Looss, 1899

Genus: Aphanurus Looss, 1909

Species: Aphanurus stossichi Monticelli, 1891

Habitat: esophagus and stomach.

Geographical distribution: Iran - Gilan Province (Anzali) (Sefidkare-Langeroudi, 1965; Mokhayer, 1976; Pazooki, Masoumian, 2012).

The Wels catfish (S. glanis) trematode parasites belong to three orders, 15 families, 24 genera and 33 species. Two orders, Strigeida and Plagiorchiida include 16 species each, while the order Aspidogastridea is presented by one species only. The family Diplostomidae is the most species-rich ( 9 species).

The farther the host is located from the center of its native range, the more affected is its parasite fauna. In Azerbaijan, where the Wels catfish exists at the southernmost boundary of its range, the number of its trematode parasites declines to 14 . Unlike the parasitic species infecting various hosts, the catfish specific trematodes occur throughout its entire range, regardless of proximity to the center. Bucephalus polymorphus, Orientocreadium siluri, and Diplostomum supathaceum are the most widespread catfish parasites; Aspidogaster limacoides, Plagioporus skrjabini and Phyllodistomum petruschewskii were recorded from Ukraine only, Allocreadium siluri and Bolboforus confusus from Uzbekistan, Asymphylodora kubanica, Bychowskycreadium bychowsky, B. schiliani, Diplostomum mergi, $D$. chromatophorum and D. paraspathaceum from Azerbaijan.

\section{References}

Abdullayeva Kh.G. (1971). Parasites and the main parasitoses of fishes in the accessory reservoirs of the lower Kura. PhD dissertation. Baku. 178 p. (in Russian)

Agapova A.I. (1966). Parasites of fishes in water reservoirs of Kazakhstan. Alma-Ata. 342 p. (in Russian) Bykhovskaya I.E., Kulakova A.P. (1987). Class Trematoda. Parasitic multicellular (second part). Vol. 3. Leningrad. P. 77-198. (in Russian)

Djikanovic V., Paunovic M., Nikolic V. et al. (2012). Parasitofauna of freshwater fishes in the Serbian open waters: a checklist of parasites of freshwater fishes in Serbian open waters. Rev. Fish Biol. Fisheries. 22, 297-324. https://doi.org/10.1007/s11160-011-9226-6

Elvira B. (2001). Identification of non-native freshwater fishes established in Europe and assessment of their potential threats to the biological diversity. Convention on the Conservation of European Wildlife and Natural Habitats. Strasbourg. 25 p.

Furhan T.M., Shamall M.A.A. (2017). Parasites of fishes of Kurdistan Region, Iraq: checklists. Biological and Applied Environmental Research, 1(2), 131-218.

Gibson D.I. (1996). Trematoda. Guide to the parasites of fishes of Canada. Part IV. Ottawa. 373 p. https://doi.org/10.1017/S0022149X00016059

Gibson D.I., Jones A., Bray A.R. (2002). Keys to Trematoda. Vol. 1. London. 228 p. https://doi.org/ 10.1079/9780851995472.0253

Gordon H.C., Robert J.B., Julien C. et al. (2009). Voracious invader or benign feline? A review of the environmental biology of Wels catfish in its native and introduced ranges. Fish and fisheries, 10, 252282. https://doi.org/10.1111/j.1467-2979.2008.00321.x

Hafize S.Ch. (2013). Metazoan parasites of fish species from Lake Sığırcı (Edirne, Turkey). Turk J. Vet. Anim. Sci., 37, 200-205. https://doi.org/10.3906/vet-1202-28

Ibrahimov Sh.R. (1977). Parasites of fish in water reservoirs of the Lenkoran natural region. PhD thesis.

Baku. 23 p. (in Russian)

Ibrahimova N.E. (2003). Catfish parasites in the changed ecological conditions of the lower Kura. International conference dedicated to the 90th anniversary of the Azerbaijan National Institute of Fisheries. Materials of the conference. Astrakhan. P. 228-231. (in Russian)

Ibrahimova N.E. (2008a). Ecological-faunistic and geographical analysis of the parasitofauna of Wels catfish (Silurus glanis L.) in the Kura River and in its reservoirs and in accessory lakes within Azerbaijan. Proceedings of ANAS, Series "Biological Sciences", 5-6, 101-108. (in Russian) 
Ibrahimova N.E. (2008b). To the study of fish parasites of the Yenikend Water Reservoir. 4th All-Russian Congress of Parasitological Society at the Russian Academy of Sciences, "Parasitology in the 21st century - problems, methods, solutions". Materials of the congress. St. Petersburg. P. 3-6. (in Russian). Ibrahimova N.E. (2009). Species composition of fish parasites recorded from the Yenikend Water Reservoir. Azerbaijan Agrarian Science, 5, 124-127. (in Azeri)

lbrahimova N.E. (2010). Parasitic fauna of fishes of the Yenikend Water Reservoir (species composition, peculiarity of formation). Biology of Kura series reservoirs. Baku. P. 241-247. (in Azeri)

lbrahimova N.E., Mikailov T.K. (2006). Parasitofauna of fishes of the Yenikend Reservoir. Proceedings of the Institute of Zoology, 27, 337-346. (in Russian)

Ibrahimova N.E., Mursalov Y.A. (2000). Helminthofauna of the catfish at the mouth of the Kura River. III International Conference "Ecology and Protection of Life". Materials of the conference. Sumgait. P. 5859. (in Russian)

Javad D.R., Masoud S., Mehrdad A., Rudabeh R. (2014). Occurrence and intensity of parasites in Wels catfish, Silurus glanis L., 1758 from the Anzali wetland, southwest of the Caspian Sea, Iran. Croatian Journal of Fisheries, 72, 25-31. https://dx.doi.org/10.14798/72.1.710

Jones A., Bray A.R., Gibson D.I. (2005). Keys to Trematoda. Vol. 2. London. 745 p.

Kaziyeva N.Sh. (1984). Parasites of fishes of the Varvara Water Reservoir. PhD thesis. Baku. 23 p. (in Russian)

Khara H., Sattari M. (2016). Occurrence and intensity of parasites in Wels catfish, Silurus glanis L. 1758 from Amirkelayeh wetland, southwest of the Caspian Sea. J. Parasit. Dis., 40(3), 848-852. https://doi.org/ 10.1007/s12639-014-0591-7

Kinzelbach R. (1992). Die westliche Verbreitungs Grenzedes Welses, Silurus glanis, an Rhine und Elbe. Fischökologie, 6, 7-20.

Kirillov A.A., Kirillova N.Yu., Evlanov I.A. (2018). Parasites of fish (Pisces) of the Samara region. Communication 2. Platyhelminthes, Nematoda and Acanthocephala. Bulletin of the Samara Scientific Center of the Russian Academy of Sciences, 5(4), 652-674. (in Russian)

Kirjušina M., Vismanis K. (2007). Checklist of the parasites of fishes of Latvia. FAO Fisheries Technical Paper. Rome. $106 \mathrm{p}$.

Kudinova M.A. (1979). On the correlative relationships of morphological systems and organs of marytes of the genus Phyllodistomum. Helminths of animals and plants (Moscow), 29, 80-88. (in Russian)

Kudinova M.A. (1990). Revision of the system of the genus Phyllodistomum Braun, 1899 (Gorgoderidae). IX All-Union Conference on Fish Parasites and Diseases. Leningrad. P. 67-68. (in Russian)

Kudinova M.A. (1994). To the revision of the trematode system of the genus Phyllodistomum Btaun, 1899 (Gorgoderidae). Ecological parasitology. Petrozavodsk. P. 96-112. (in Russian)

Kurbanova A.I., Urazbaev A.N., Yusupov O.Yu. (2002). Changes in parasite fauna of certain fish species in the Southern Aral Sea under anthropogenic pressure. Vestnik Zoologii, 36, 29-34.

Markevich A.P. (1951). Parasitofauna of freshwater fish of the Ukrainian SSR. 376 p. (in Russian)

Mikailov T.K. (1975). Parasites of fish in water reservoirs of Azerbaijan. Baku. 299 p. (in Russian)

Mikailov T.K., Ibrahimova N.E. (2001). Comparative analysis of the parasitofauna of catfish in the Lower Kura reservoirs over the period from the 60s until 2000. Scientific conference dedicated to the $80^{\text {th }}$ anniversary of Academician M.A. Musayev. Materials of the conference. Baku. P. 264-267. (in Russian) Mikailov T.K., Ibrahimova N.E., Kaziyeva N.Sh. (2001). Modern state of parasitic fauna of Catfish (Silurus glanis L.). Scientific conference dedicated to the $80^{\text {th }}$ anniversary of Academician M.A. Musayev. Materials of the conference. Baku. P. 177-179. (in Azeri)

Mineeva O.V. (2016). Fish contamination of the Saratov reservoir with an alien parasite Nicolla skrjabini (Iwanitzky, 1928) (Trematoda, Opecoelidae). Russian Journal of Biological Invasions, 2, 92-101. (in Russian)

Mokhayer B. (1976). Fish diseases in Iran. Revista italiana di Piscicoltura e Ittiopatologia, 11, 123-128.

Moravec K. (2001). Checklist of the metazoan parasites of fishes of the Czech Republic and the Slovak Republic (1873-2000). Academia. $168 \mathrm{p}$.

Murvanidze L., Nikolaishvili K., Lomidze Ts. (2018). Checklist of helminth parasites of freshwater fishes of Georgia. Proceedings of the Institute of Zoology (Academic Press of Georgia), 26, 91-124.

Niewiadomska K. (1984). Present status of Diplostomum spathaceum (Rudolphi, 1819) and differentiation of Diplostomum paraspathaceum nom. nov. (Trematoda: Diplostomidae). Syst. Parasitol., 6(2), 81-86. https://doi.org/10.1007/bf02185515 
Niewiadomska K. (1986). Verification of the life cycles of Diplostomum spathaceum (Rudolphi, 1819) and Diplostomum paraspathaceum Niewiadomska, 1984 (Trematoda: Diplostomidae). Syst. Parasitol., 8, 2331. https://doi.org/10.1007/BF00010306

Osmanov S.O. (1971). Parasites of fishes in Uzbekistan. Tashkent. 532 p. (in Russian)

Pazooki J., Masoumian M. (2012). Synopsis of the Parasites in Iranian Freshwater Fishes. Iranian Journal of Fisheries Sciences, 11(3), 570-589.

Pigulevsky S.V. (1953). Family Gorgoderidae Looss, 1901. Trematodes of animals and human. Fundamentals of trematodology. Vol. 8. Moscow. P. 253-615. (in Russian)

Pugachev O.N. (2003). Checklist of parasites of freshwater reservoirs in North Asia. Trematodes. Proceedings ZIN RAS, 298. 224 p. (in Russian)

Rubanova M.V., Rubanov E.S. (2015). Catfish helminth fauna Siluris glanis L., 1758, Saratov reservoir. Ecological collection 5: Proceedings of young scientists of the Volga region, 313-315. (in Russian)

Scarlato O.A. (1987). Identification Guide to the parasites of freshwater fishes of the USSR. Vol. 3. Parasitic multicellular. Leningrad. 583 p. (in Russian)

Skryabin K.I., Gushanskaya L.Kh. (1956). Suborder Azygiata La Rue, 1957. Trematodes of animals and human. Fundamentals of trematodology. Vol. 14. Moscow. P. 670-824. (in Russian)

Skryabin K.I., Koval V.P. (1966). Suborder Allocreadiata Skrjabin, Petrow et Koval, 1958. Trematodes of animals and human. Fundamentals of trematodology. Vol. 22. Moscow. P. 175-458. (in Russian)

Sefidkare-Langeroudi Y. (1965). Silurus glanis and its intestinal parasites in Anzali wetland. DVM thesis. Faculty of Veterinary Medicine. Tehran. $31 \mathrm{p}$.

Seyidli Y.M. (1992). Parasitofauna of fish of the Greater Kyzyl-Agach Bay of the Caspian Sea. PhD dissertation. Baku. 188 p. (in Russian)

Shigin A.A. (1965). Some results of the study of the taxonomy of metacercariae of the genus Diplostomum - the causative agent of diplostomoses in freshwater fishes in USSR. Scientific conference of the All-Union Society of Helmintologists. Materials of the conference. Part 1. Moscow. P. 261-265. (in Russian)

Shigin A.A. (1976). Metacercaria of the genus Diplostomum of the fauna of the USSR. Parasitology. 10(4), 346-351. (in Russian)

Shigin A.A. (1986). Trematodes of the fauna of the USSR. Genus Diplostomum. Metacercaria. Moscow. 253 p. (in Russian)

Shigin A.A. (1987). Morphology, biology, and taxonomy of marita Diplostomum chromatophorum (Brown, 1931) Shigin, 1986 (Trematoda: Diplostomidae). Proc. Helminthol. Lab., the USSR Acad. of Sci., 35, 176-182. (in Russian)

Shigin A.A. (1993). Trematodes of the fauna of Russia and adjacent regions. Genus Diplostomum. Marita. Moscow. 207 p. (in Russian)

Sobolev A.A. (1955). Family Monorchidae Odhner, 1911. Trematodes of animals and human. Fundamentals of trematodology. Vol. 11. Moscow. P. 257-466. (in Russian)

Soylu E. (1990). Surveys on the parasite fauna of some fishes in Sapanca Lake. Istanbul University, Marine Science Institution. Dr. thesis. $85 \mathrm{p}$.

Stone R. (2007). The last of the Leviathans. Science, 316, 1684-1688. https://doi.org/ 10.1126/science.316.5832.1684

Sudarikov V.E. (1971). Order Strigeidida (La Rue, 1926) Sudarikov, 1959. Metaceracaria. Trematodes of animals and humans. Fundamentals of trematodology. Vol. 24. Moscow. P. 69-272. (in Russian)

Sudarikov V.E. (1984). Trematodes of the fauna of the USSR. Strigides. Moscow. 168 p. (in Russian)

Yakhchali M., Tehrani A.A., Ghoreishi M. (2012). The occurrence of helminth parasites in the gastrointestinal of catfish (Silurus glanis Linnaeus 1758) from the Zarrine-roud river, Iran. Veterinary Research Forum, 3(2), 143-145.

\section{Систематичний огляд паразитів (Plathelminthes: Trematoda) європейського сома (Silurus glanis L., 1758) \\ H.E. Ібрагімова}

Європейський, або звичайний сом (Silurus glanis L., 1758) є однією з важливих промислових риб. Його природний ареал простягається від Східної Європи до Західної Азії. Останнім часом ареал сома розширився завдяки інтродукції як на захід, так і на південь. Європейський сом в водоймах Азербайджану знаходиться на найпівденнішій межі свого ареалу і зустрічається в р. Кура та її басейні. Оглядових паразитологічних робіт, 
присвячених вивченню трематод європейського сома, немає. У дослідження були залучені не усі систематичні групи паразитів, або ж не були охоплені всі території, на яких поширена ця риба. 3 використанням літературних даних був підготовлений систематичний огляд трематод європейського сома в межах його ареалу (природний ареал і території, куди було здійснено інтродукцію), у тому числі території Азербайджану. Для кожного виду вказуються місця виявлення, синоніми, локалізація, показники інвазії та автори, які виявили паразитів в межах ареалу європейського сома. У роботі використана система паразитичних організмів, опублікована в «Каталозі паразитів прісноводних риб Північної Азії». Крім того, автор врахував нові дослідження в області систематики трематод. Таким чином, у європейського, або звичайного сома було зареєстровано 33 види паразитів-трематод. Сосальники, виявлені в європейського сома, належать до 3 рядів (Aspidogastridea - 1 вид, Strigeida - 16 видів, Plagiorchiida - 16 видів), 15 родин, 24 родів. 3 них 14 видів поширені в водоймах Азербайджану. Домінуючою за кількістю видів трематод у сома є родина Diplostomidae (9 видів). Три види (Bucephalus polymorphus, Orientocreadium siluri, Diplostomum spathaceum) широко розповсюджені по всьому ареалу сома. Встановлено, що Aspidogaster limacoides, Plagioporus skrjabini, Phyllodistomum petruschewskii зустрічаються тільки в Україні, Allocreadium siluri, Bolboforus confusus - в Узбекистані, та Asymphylodora kubanica, Bychowskycreadium bychowsky, Bychowskycreadium schiliani, Diplostomum mergi, Diplostomum chromatophorum, Diplostomum paraspathaceum - в Азербайджані.

Ключові слова: трематоди, систематичний список, паразити звичайного сома, показники інвазії, географрічне поширення.

\section{Про автора:}

Н.Е. Ібрагімова - Інститут зоології НАН Азербайджану, вул. А. Аббасзаде, проїзд 1128, квартал 504, Баку, Азербайджан, AZ1004, ibragimova.n.e@mail.ru, https://orcid.org/0000-0002-4531-3823

\section{Систематический обзор паразитов (Plathelminthes: Trematoda) европейского сома (Silurus glanis L., 1758) Н.Э. Ибрагимова}

Европейский, или обыкновенный сом (Silurus glanis L., 1758) является одной из важных промысловых рыб. Его естественный ареал простирается от Восточной Европы до Западной Азии. В последнее время ареал сома расширился благодаря интродукции как на запад, так и на юг. Европейский сом в водоемах Азербайджана находится на самой южной границе своего ареала и встречается в р. Кура и её бассейне. Обзорных паразитологических работ, посвященных изучению трематод европейского сома, нет. Исследованиями были затронуты не все систематические группы паразитов, или же не были охвачены все территории, на которых распространена данная рыба. С использованием литературных данных был подготовлен систематический обзор трематод европейского сома в пределах его ареала (естественный ареал и территории, куда была осуществлена интродукция), в том числе территории Азербайджана. Для каждого вида указываются места обнаружения, синонимы, локализация, показатели инвазии и авторы, обнаружившие паразитов в пределах ареала европейского сома. В работе использована система паразитических организмов, опубликованная в «Каталоге паразитов пресноводных рыб Северной Азии». Кроме того, автор учел новые исследования в области систематики трематод. Таким образом, у европейского или обыкновенного сома было зарегистрировано 33 вида паразитов-трематод. Сосальщики, обнаруженные у европейского сома, относятся к 3 отрядам (Aspidogastridea - 1 вид, Strigeida - 16 видов, Plagiorchiida - 16 видов), 15 семействам, 24 родам. Из них 14 видов распространены в водоемах Азербайджана. Преобладающим по числу видов трематод у сома является семейство Diplostomidae (9 видов). Три вида (Bucephalus polymorphus, Orientocreadium siluri, Diplostomum spathaceum) широко распространены по всему ареалу сома. Установлено, что Aspidogaster limacoides, Plagioporus skrjabini, Phyllodistomum petruschewskii встречаются только в Украине, Allocreadium siluri, Bolboforus confusus - в Узбекистане, и Asymphylodora kubanica, Bychowskycreadium bychowsky, Bychowskycreadium schiliani, Diplostomum mergi, Diplostomum chromatophorum, Diplostomum paraspathaceum в Азербайджане.

Ключевые слова: трематоды, систематический список, паразиты обыкновенного сома, показатели инвазии, географическое распространение.

\section{Oб авторе:}

Н.Э. Ибрагимова - Институт зоологии НАН Азербайджана, ул. А. Аббасзаде, проезд 1128, квартал 504, Баку, Азербайджан, AZ1004, ibragimova.n.e@mail.ru, https://orcid.org/0000-0002-4531-3823

Подано до редакції / Received: 20.05.2020 